\title{
Hubungan Budaya Organisasi Dengan Kinerja Pegawai Dinas Kesehatan Kota Bogor
}

\author{
Herman $^{1}$, Eris Delia ${ }^{2}$ \\ ${ }^{1,2}$ Fakultas Ekonomi Universitas Pakuan
}

\begin{abstract}
Organizational culture is a basic philosophy that makes shared beliefs, norms and values a core characteristic of how to do things in an organization. Organizational culture is very necessary and important role to achieve the organization's peak performance. The purpose of this study is (1) To find out the organizational culture found in the Bogor City Health Office. (2) to find out the performance of the employees of the Bogor City Health Office. (3) to determine the relationship of organizational culture with the performance of employees of the Bogor City Health Office. This research was conducted at the government agency of the Bogor City Health Office. The sample used in this study was 56 people. This type of research is Explorative Descriptive using primary and secondary data, with the method of observation and questionnaire distributed to 56 respondents. The data analysis method used is Spearman rank correlation coefficient analysis, analysis of the coefficient of determination, and the correlation hypothesis test is processed using SPSS 23. Spearman rank correlation coefficient analysis results obtained $r=0.544$, meaning that the relationship of organizational culture with the performance of employees of the Bogor City Health Office has a moderate level of relationship. The results of the analysis of the coefficient of determination obtained KD $=29.6 \%$. The results of the analysis show that the contribution of organizational culture relations with the performance of large employees is $29.6 \%$. While the remaining $70.4 \%$ is influenced by other factors in employee performance. Correlation hypothesis test results obtained $t$ value $>t$ table (4.764> 1.674) then $\mathrm{Ha}$ is accepted $\mathrm{Ho}$ is rejected, then, it can be concluded that there is a positive and real relationship between organizational culture $(\mathrm{X})$ with employee performance $(\mathrm{Y})$ at the Health Office of Bogor City .
\end{abstract}

Keywords: Organizational Culture and Employee Performance

\begin{abstract}
Abstrak. Budaya organisasi adalah filosofi dasar yang membuat keyakinan, norma-norma,dan nilai-nilai bersama yang menjadi karakteristik inti tentang bagaimana cara melakukan sesuatu dalam organisasi. Budaya organisasi sangat diperlukan dan berpera penting untuk mencapai kinerja puncak organisasi. Tujuan dari penelitian ini adalah (1) Untuk mengetahui budaya organisasi yang terdapat pada Dinas Kesehatan Kota Bogor. (2) untuk mengetahui kinerja pegawai Dinas Kesehatan Kota Bogor. (3) untuk mengetahui hubungan budaya organisasi dengan kinerja pegawai Dinas Kesehatan Kota Bogor. Penelitian ini dilakukan di instansi pemerintahan Dinas Kesehatan Kota Bogor. Sampel yang digunakan pada penelitian ini adalah 56 orang. Jenis penelitian yang di gunakan adalah Deskriptif Eksploratif menggunakan data primer dan sekunder, dengan metode observasi dan kuesioner dibagikan kepada 56 responden. Metode analisis data yang digunakan analisis koefisien korelasi rank spearman, anlisis koefisien determinasi, dan uji hipotesis korelasi diolah dengan menggunakan SPSS 23. Hasil analisis koefisien korelasi rank spearman diperoleh $r=0,544$, artinya hubungan budaya organisasi dengan kinerja pegawai Dinas Kesehatan Kota Bogor memiliki tingkat hubungan yang sedang. Hasil analisis koefisien determinasi diperoleh $\mathrm{KD}=29,6 \%$. Hasil analisis tersebut menunjukan bahwa kontribusi hubungan budaya organisasi dengan kinerja pegawai besar $29,6 \%$. Sedangkan sisanya sebesar 70,4\% dipengaruhi oleh faktor-faktor lain di kinerja pegawai. Hasil uji hipotesis korelasi diperoleh nilai t hitung > t tabel $(4,764>1,674)$ maka Ha diterima Ho ditolak, maka, dapat disimpulkan bahwa terdapat hubungan yang positif dan nyata antara budaya organisasi (X) dengan kinerja pegawai (Y) pada Dinas Kesehatan Kota Bogor.
\end{abstract}

Kata kunci : Budaya Organisasi dan Kinerja Karyawan

\section{A. PENDAHULUAN}

Permasalahan mengenai sumber daya manusia pada saat sekarang ini masih menjadi pusat perhatian dan fokus utama bagi perusahaan ataupun instansi pemerintahan dimanapun berada. Seiring berkembangnya ilmu pengetahuan dan teknologi, sumber daya manusia pun membutuhkan banyak cara agar dapat menyeimbangkan kemajuan tersebut agar terwujudnya kinerja yang 
memuaskan sesuai dengan harapan suatu organisasi. Sumber daya manusia merupakan salah satu aset dalam suatu organsasi yang sangat penting, yang merupakan sumber daya yang menggerakan dan mengendalikan sumber daya-sumber daya yang lain seperti material, modal, dan mesin. Sumber daya tersebut tidak dapat berjalan dan beroperasi dengan baik jika tidak ada sumber daya manusia yang mengelolanya dalam organisasi.

Organisasi merupakan sebuah kelompok yang berisikan orang-orang yang memiliki tujuan tertentu untuk dicapai. Secara langsung ataupun tidak langsung, sikap dan perilaku setiap orang yang berada dalam suatu organisasi dapat mempengaruhi proses dalam mencapai tujuan bersama yang telah ditetapkan sebelumnya dalam organisasi tersebut. Keberhasilan dan pencapaian tujuan yang diraih oleh organisasi dapat tercermin dari ketermapilan dan kemampuan setiap sumber daya manusia yang ada dalam organisasi tersebut. Karena tujuan organisasi dapat diraih dengan adanya upaya yang dilakukan setiap anggota organisasi.

Organisasi harus memiliki sumber daya manusia yang kreatif serta mampu bekerja sama demi mendukung organisasi mencapai tujuannya. Dalam pelaksanaan tugas dan pekerjaan tersebut terdapat suatu tujuan yang sama yaitu mengharapkan hasil yang baik serta memuaskan. Untuk mendapatkan hasil kinerja yang baik dan sesuai dengan tujuan organisasi maka setiap organisasi mempunyai suatu aturan yang dituangkan dalam bentuk kebijakan. Kebijakan ini dibuat dengan tujuan agar setiap komponen organisasi melaksanakan tugas sesuai dengan tujuan yang telah ditetapkan agar tercipta kinerja yang baik.

Sumber daya manusia dalam sebuah organisasi saling berinteraksi untuk bekerja sama dalam mencapai tujuan organisasi. Dalam proses memperoleh, melatih, menilai, dan memberikan kompensasi kepada karyawan, memperhatikan hubungan kerja mereka, kesehatan, keamanan dan masalah keadilan. Secara umum sumber daya manusia merupakan suatu alat untuk melatih, menilai, serta memperhatikan hubungan kerja yang ada pada sebuah organisasi, dengan tujuan agar sumber daya manusia yang ada dapat memberikan kinerja yang optimal bagi organisasi perusahaan.

Kinerja pegawai merupakan hasil kerja yang dicapai seseorang dalam melaksanakan tugas-tugas yang dibebankan kepadanya dalam bentuk tanggung jawab untuk mencapai target kerja. Kinerja yang baik sangat penting dimiliki oleh pegawai karena dengan kinerja atau hasil kerja yang baik maka akan memudahkan organisasi maupun pegawai itu sendiri untuk mencapai tujuan yang baik pula. Artinya untuk mencapai suatu tujuan maka harus disertai dengan kinerja yang sesuai dengan yang diharapkan.

Demikian juga dengan Dinas Kesehatan Kota Bogor mempunyai tugas dalam melaksanakan kewenangan pemerintahan daerah dan tugas pembantuan di bidang Kesehatan, dengan fungsi perumusan kebijakan teknis, pelaksanaan dan pengendalian, pembinaan dan perizinan dibidang kesehatan yang terdiri dari Kepala Dinas, Sumber Daya Kesehatan, Kesehatan Masyarakat, Pelayanan Kesehatan dan bagian Pengendalian dan Pencegahan Penyakit.

Namun demikian hal ini terlihat dari masih banyak pegawai yang belum mematuhi peraturan-peraturan yang menjadi pedoman bagi pegawai dan disiplin kerja yang ditetapkan oleh Dinas Kesehatan Kota Bogor. Berdasarkan survey pendahuluan, peneliti medapatkan informasi kedisiplinan dan 
ketaatan kerja para pegawai melalui kepala bagian Sub Bagian Umum dan Kepegawaian yang menyebutkan bahwa masih banyak pegawai yang kurang disiplin yaitu datang tidak tepat waktu, tidak melakukan Fingerprint, banyaknya karyawan yang absen tanpa keterangan (alpa), izin keluar pada saat jam kantor, izin tidak masuk kerja, dan banyaknya karyawan datang terlambat setelah jam istirahat.

Untuk melihat kinerja karyawan salah satunya bisa dilihat dari penilaian prestasi kerja pegawai Dinas Kesehatan Kota Bogor. Berikut data penilaian prestasi kerja pegawai dalam bulan Januari-Desember 2017 pada Dinas Kesehatan Kota Bogor pada tabel berikut:

Tabel 1. Penilaian Prestasi Kerja Pegawai Dinas Kesehatan Kota Bogor Jangka Waktu Penilaian Januari Desember 2017

\begin{tabular}{|l|c|c|c|}
\hline \multicolumn{1}{|c|}{ Bidang } & $\begin{array}{c}\text { Target } \\
\text { Prestasi } \\
\text { Kerja }\end{array}$ & Waktu & Realisasi \\
\hline Sumber Daya Kesehatan & 100 & 12 Bulan & 68,60 \\
\hline Kesehatan Masyarakat & 100 & 12 Bulan & 70,48 \\
\hline Pelayanan Kesehatan & 100 & 12 Bulan & 70,23 \\
\hline $\begin{array}{l}\text { Pencegahan dan } \\
\text { Pengendalian Penyakit }\end{array}$ & 100 & 12 Bulan & 78,28 \\
\hline
\end{tabular}

(Sumber Dinas Kesehatan Kota Bogor). 2018

Berdasarkan tabel 1 penilaian prestasi kerja pegawai tidak memenuhi target yang telah ditetapkan oleh perusahaan, serta dapat dikatakan prestasi kerja tersebut belum dapat dikatakan sangat baik. Dengan terjadinya realisasi tidak mencapai target dapat dilihat kurangnya kinerja pegawai dan perlu dilakukan upaya yang dapat meningkatkan kinerja pegawai Dinas Kesehatan Kota Bogor.

Adapun hasil penilaian prestasi kinerja pegawai Dinas Kesehatan Kota Bogor harus memperhatikan standar kinerja pegawainya. Berikut di sajikan penilian prestasi kinerja pegawai yang ditetapkan oleh Dinas Kesehatan Kota Bogor.
Tabel 2. Standar Peniliaian Prestasi Kerja Pegawai Dinas Kesehatan Kota

\begin{tabular}{|l|l|l|}
\multicolumn{3}{|c|}{ Ramar } \\
\hline No & \multicolumn{1}{|c|}{ Standar Penilaian } & \multicolumn{1}{|c|}{ Kategori } \\
\hline 1 & $91-100$ & Sangat Baik \\
\hline 2 & $81-90$ & Baik \\
\hline 3 & $70-79$ & Cukup \\
\hline 4 & $61-69$ & Kurang \\
\hline 5 & Dibawah 60 & Buruk \\
\hline
\end{tabular}

(Sumber Dinas Kesehatan Kota Bogor). 2018

Turunnya kinerja pegawai disebabkan oleh beberapa faktor diantaranya adalah kedisiplinan, lingkungan kerja, kompensasi serta budaya organisasi. Hal ini dapat terlihat dari tingkat absensi pegawai Dinas Kesehatan Kota Bogor. Berikut ini data absensi pegawai dalam bulan JanuariDesember 2017 pada Dinas Kesehatan Kota Bogor pada tabel berikut:

\section{Tabel 3 Tingkat Absensi Pegawai Dinas Kesehatan Kota Bogor Bulan Januari-Desember 2017}

\begin{tabular}{|c|c|c|c|c|c|c|c|c|c|c|c|c|c|c|c|c|c|c|}
\hline \multirow[t]{2}{*}{ Bulan } & \multirow{2}{*}{$\begin{array}{l}\text { Hari } \\
\text { Kerja }\end{array}$} & \multicolumn{4}{|c|}{$\begin{array}{l}\text { Sumber Daya } \\
\text { Kesehatan }\end{array}$} & \multicolumn{5}{|c|}{$\begin{array}{c}\text { Kesehatan } \\
\text { Masyarakat }\end{array}$} & \multicolumn{4}{|c|}{$\begin{array}{l}\text { Pelayanan } \\
\text { Kesehatan }\end{array}$} & \multicolumn{4}{|c|}{$\begin{array}{c}\text { Pencegahan dan } \\
\text { Pengendalian } \\
\text { Penyakit }\end{array}$} \\
\hline & & $\mathrm{Jml}$ & $\mathrm{S}$ & \begin{tabular}{l|l}
$\mathrm{A}$ & $\mathrm{I}$
\end{tabular} & $\begin{array}{ll}I & \text { Tot }\end{array}$ & $1 \mathrm{Jm}$ & $\mathrm{S}$ & A & $\begin{array}{ll}\mathrm{I} & \mathrm{T}\end{array}$ & Total & $\mathrm{Jml}$ & \begin{tabular}{l|l} 
S & A
\end{tabular} & A I & Total & $\mathrm{Jml}$ & $\mathrm{s}$ & \begin{tabular}{l|l}
$A$ & I
\end{tabular} & \begin{tabular}{l|l|l} 
I & Total
\end{tabular} \\
\hline Januari & 22 & 14 & 2 & \begin{tabular}{l|l}
45 & 5
\end{tabular} & 11 & 16 & 6 & 3 & 1 & 10 & 20 & \begin{tabular}{|l|l|}
5 & 6 \\
\end{tabular} & \begin{tabular}{l|l}
6 & 2 \\
\end{tabular} & 13 & 21 & 3. & \begin{tabular}{l|l}
4 & 3 \\
\end{tabular} & 10 \\
\hline Februari & 22 & 16 & 4 & \begin{tabular}{l|l}
0 & 4
\end{tabular} & 8 & 20 & 3 & 5 & 1 & 9 & 28 & \begin{tabular}{|l|l|}
6 & 1 \\
\end{tabular} & 13 & 10 & 35 & \begin{tabular}{|l|l|} 
& \\
\end{tabular} & \begin{tabular}{l|l}
1 & 4 \\
\end{tabular} & 12 \\
\hline Maret & 22 & 16 & 4 & \begin{tabular}{|l|l|}
2 & 3
\end{tabular} & 9 & 20 & 0 & 2 & 5 & 7 & 28 & \begin{tabular}{|l|l|}
4 & 3 \\
\end{tabular} & \begin{tabular}{l|l}
3 & 1 \\
\end{tabular} & 8 & 35 & 5 & 2 & 13 \\
\hline April & 22 & 16 & 5 & \begin{tabular}{l|l}
0 & 4 \\
\end{tabular} & 9 & 20 & 3 & 3 & 6 & 12 & 28 & \begin{tabular}{|l|l|}
7 & 3 \\
\end{tabular} & \begin{tabular}{l|l}
32 \\
\end{tabular} & 12 & 35 & \begin{tabular}{|l|l}
3 \\
\end{tabular} & \begin{tabular}{l|l}
3 & 8 \\
\end{tabular} & 15 \\
\hline Mei & 22 & \begin{tabular}{|l|}
17 \\
\end{tabular} & 3 & \begin{tabular}{l|l}
2 & 6
\end{tabular} & 11 & 20 & 0 & 1 & 4 & 5 & 28 & \begin{tabular}{|l|l|}
8 & 4 \\
\end{tabular} & \begin{tabular}{l|l}
4 & 2
\end{tabular} & 14 & 35 & \begin{tabular}{|l|}
2 \\
\end{tabular} & \begin{tabular}{|l|l}
2 & 3
\end{tabular} & 7 \\
\hline Juni & 22 & 17 & 2 & \begin{tabular}{l|l}
0 & 3
\end{tabular} & 5 & 20 & 0 & 8 & 0 & 8 & 28 & \begin{tabular}{|l|l|}
4 & 4 \\
\end{tabular} & \begin{tabular}{l|l}
45 \\
\end{tabular} & 13 & 35 & \begin{tabular}{l|}
1 \\
\end{tabular} & \begin{tabular}{l|l}
99 & 0 \\
\end{tabular} & 10 \\
\hline Juli & 22 & 17 & 3 & 21 & 1 & 20 & 0 & 7 & 3 & 10 & 28 & \begin{tabular}{|l|l|}
1 & 4 \\
\end{tabular} & \begin{tabular}{l|l}
4 & 4
\end{tabular} & 9 & 35 & \begin{tabular}{|l|}
3 \\
\end{tabular} & \begin{tabular}{l|l}
9 & 1 \\
\end{tabular} & 13 \\
\hline Agustus & 22 & 17 & 4 & $\begin{array}{ll}3 & 1 \\
\end{array}$ & 8 & 20 & 2 & 4 & 5 & 11 & 28 & \begin{tabular}{|l|l|}
5 & 0 \\
\end{tabular} & \begin{tabular}{l|l}
0 & 0
\end{tabular} & 5 & \begin{tabular}{|l|}
21 \\
\end{tabular} & 3 & 46 & 7 \\
\hline September & 22 & 17 & 4 & 0 & 4 & 20 & 0 & 0 & 5 & 5 & 28 & \begin{tabular}{|l|l|}
4 & 2 \\
\end{tabular} & 22 & 8 & 21 & \begin{tabular}{|l|}
4 \\
\end{tabular} & 38 & 15 \\
\hline \begin{tabular}{|l|} 
Oktober \\
\end{tabular} & 22 & 17 & 5 & 50 & 10 & 20 & 2 & 5 & 0 & 7 & 28 & \begin{tabular}{|l|l|}
6 & 3 \\
\end{tabular} & \begin{tabular}{l|l}
3 & 4 \\
\end{tabular} & 13 & 21 & 0 & 5 & 9 \\
\hline November & 22 & 17 & 5 & 25 & 12 & 20 & 0 & 0 & 4 & 4 & 28 & \begin{tabular}{|l|l}
5 & 4 \\
\end{tabular} & 42 & 11 & 21 & 4 & 82 & 14 \\
\hline Desember & 22 & 17 & 6 & 54 & 15 & 20 & 6 & 1 & 6 & 13 & 28 & \begin{tabular}{|l|l|}
6 & 1 \\
\end{tabular} & 10 & 7 & 21 & \begin{tabular}{|l|}
5 \\
\end{tabular} & 4 & 9 \\
\hline Jumlah & & & & & 10 & & & & & 101 & & & & 123 & & & & 134 \\
\hline
\end{tabular}

(Sumber: Dinas Kesehatan Kota Bogor),2018

Dapat dilihat dari tabel diatas, jumlah pegawai bagian bidang Sumber Daya Kesehatan pada bulan Januari sebanyak14 orang dan Februari-April 2017 sebanyak 16 orang dan pada bulan Mei-Desember 2017, kehadiran pegawai jauh dari harapan terlihat dari ketidak hadiran dalam satu tahun 2017 pegawai yang tidak masuk kerja total keseluruhanya sebanyak 108 orang jumlah pegawai yang tidak hadir. Pada pegawai bagian bidang Kesehatan Masyarakat pada bulan Januari sebanyak 
16 orang dan sebanyak 20orang pada bulan Februari-Desember 2017, kehadiran pegawai jauh dari harapan terlihat dari ketidak hadiran dalam satu tahun 2017 pegawai yang tidak masuk kerja total keseluruhanya sebanyak 101 orang jumlah pegawai yang tidak hadir. Sedangkan jumlah pegawai bagian bidang Pelayanan Kesehatan pada bulan Januari sebanyak 20 orang dan sebanyak 28 orang pada bulan Februari-Desember 2017, kehadiran pegawai jauh dari harapan terlihat dari ketidak hadiran dalam satu tahun 2017 pegawai yang tidak masuk kerja total keseluruhanya sebanyak 123 jumlah pegawai yang tidak hadir. Dan jumlah pegawai bagian bidang Pencegahan dan Pengendalian Penyakit pada bulan Januari sebanyak 21 orang dan pada bulan Februari-Juni 35 orang dan pada bulan juli sebanyak 33 orang dan sebanyak 21 orang pada bulan Agustus-Desember, kehadiran pegawai jauh dari harapan terlihat dari ketidak hadiran dalam satu tahun 2017 pegawai yang tidak masuk kerja total keseluruhanya sebanyak 134jumlah pegawai yang tidak hadir.

Budaya organisasi yang kuat akan cenderung memberikan rasa saling mendukung terhadap pencapaian perusahaan. Budaya organisasi yang kuat membuat individu yang ada didalamnya merasa bangga akan perusahaan dan memegang prinsipprinsip perusahaan yang telah tertanam dengan nilai-nilai yang disadari atau tidak disadari, serta digunakan oleh semua elemen dalam perusahaan. Sebaliknya perusahaan yang memiliki budaya organisasi yang lemah cenderung akan sulit dalam menciptakan lingkungan kerja yang nyaman sehingga dapat berdampak pada kinerja pegawai yang kurang optimal.

Budaya organisasi merupakan filosofi dasar organisasi yang membuat keyakinan, norma-norma, dan nilai-nilai bersama yang menjadi karakteristik inti tentang bagaimana cara melakukan dan berperan penting untuk mencapai kinerja puncak organisasi. Budaya organisasi harus selalu bergerak, berubah, dan melakukan transformasi sesuai dengan kebutuhan organisasi dalam menanggapi perubahan lingkungan strategis. Oleh karena itu budaya organisasi berperan sebagai alat pembeda antara suatu organisasi perusahaan dengan organisasi perusahaan lainnya. Norma-norma dan nilai-nilai tersebut dapat dijadikan tolak ukur atau pandangan bagi setiap individu dalam bertingkah laku serta dalam sesuatu yang berkaitan dengan pekerjaan di dalam suatu organisasi.

Berikut adalah aturan-aturan dengan perubahan keputusan Walikota Bogor Nomor 061.2.45-72 tahun 2010 tentang ketentuan hari dan jam kerja di lingkungan pemerintahan Kota Bogor.

1. Hari kerja ditetapkan 5 (lima) hari kerja yaitu mulai hari senin sampai dengan jum'at Jam Kerja Efektif selama 37 jam 30 menit (tga puluh tujuh jam tiga puluh menit) per minggu diluar Istirahat dan Olah Raga, dipergunakan untuk melaksanakan tugas pokok dan fungsi kedinasan dan tidak boleh diganggu untuk kegiatankegiatan lain diluar kedinasan.

2. Jam kerja sebagaimana yang dimaksud adalah sebagai berikut :

a. Senin sampai dengan Kamis

Masuk Kerja : pukul 07.30 WIB Istirahat : pukul 12.00-12.45 WIB

Pulang Kerja : pukul 15.30 WIB b. Jum'at

Masuk Kerja : pukul 07.30 WIB Istirahat : pukul 11.30-13.00 WIB Pulang Kerja : pukul 15.30 WIB

3. Pada hari dan jam kerja para pegawai diwajibkan memakai Pakaian Dinas yang berlaku pada waktu itu, lengkap dengan atribut papan nama dan lencana KORPRI serta mengikuti apel 
pagi dan apel sore.

4. Terhadap unit kerja yang bersifat memberikan pelayanan kepada masyarakat sebagaimana tercantum dalam lampiran keputusan ini, agar mengatur jadwal piker pada hari Sabtu dari Pukul 07.30 WIB sampai dengan pukul 12.00 WIB.

Dalam sebuah budaya dapat menjadi identitas bagi organisasi. Budaya yang ada pada organisasi akan mencerminkan citra organisasi di mata orang lain. Apabila budaya tersebut bersifat positif maka akan bercitra positif pula,begitupun sebaliknya jika budaya organisasi bersifat negative makan citra perusahaan dimata orang lainpun akan buruk. Budaya organisasi akan mempengaruhi setiap individu untuk menjadi peminpin yang otoriter atau menjadi peminpin yang bersahaja, menjadi pekerja yang individualis atau mampu bekerja sama dengan baik serta menjadikan individu dalam organisasi untuk mampu bekerja lebih cepat atau lambat. Atas dasar tersebutlah, budaya organisasi memiliki pengaruh yang kuat terhadap perilaku anggotanya sekaligus kedisiplinan dan kinerjanya.

Dinas Kesehatan Kota Bogor mempunyai 10 budaya malu diantaranya yaitu :

1. Malu karena datang terlambat

2. Malu melihat rekan sibuk melakukan aktivitas

3. Malu menuntut hak namun tidak tahu kewajiban

4. Malu karena sering minta izin tidak masuk kerja

5. Malu karena bekerja tidak sesuai dengan aturan

6. Malu karena tidak berpakai tidak sesuai dengan aturan

7. Malu karena tugas tidak terlaksana tepat waktu

8. Malu berperilaku dan berbicara tidak sopan
9. Malu meroko dilingkungan kantor

10. Malu tidak menjaga kebersihan, keindahan tempat kerja dan lingkungan kantor.

Berdasarkan uraian diatas maka penulis tertarik untuk mengadakan penelitian dengan judul "Hubungan Budaya Organisasi Dengan Kinerja Pegawai Dinas Kesehatan Kota Bogor".

\section{Kerangka Pemikiran}

Manajemen sumber daya manusia merupakan suatu kegiatan untuk mengelola semua unsur yang berkaitan dengan kegiatan individu sebagai angota organisasi. Setiap individu (dalam hal ini pegawai) tentu sudah dibekali dengan sikap kedisiplinan, norma, nilai, tanggung jawab yang tinggi yang telah dibentuk oleh organisasi hal ini agar kinerja perusahaan dapat tercapai sesuai dengan yang telah ditetapkan oleh perusahaan. Dalam sebuah organisasi, banyak faktor yang dapat mempengaruhi tingkat kinerja, salah satunya adalah budaya organisasi. Budaya organisasi merupakan filosofi dasar organisasi yang membuat keyakinan, normanorma, dan nilai-nilai bersama yang menjadi karakteristik inti tentang bagaimana cara melakukan sesuatu dalam organisasi.

Budaya organisasi berhubungan dengan keberartian bersama dimana budaya organisasi berkepentingan dengan bagaimana pekerja merasakan karakteristik budaya organisasi tentang sama dengan mereka atau tidak sama dengan mereka. Budaya organisasi dapat disimpulkan sebagai keyakinan, nilai, norma dan pola perilaku dalam melakukan suatu hal. Keyakinan adalah asumsi atau presepsi tentang sesuatu, orang dan orgnaisasi secara keseluruhan, di terima sebagai suatu yang benar dan layak. Core values adalah nilai dominan 
atau inti, yang diteriman di seluruh organisasi. Pola perilaku adalah cara orang bertindak satu sama lain. Pengertian ini menekankan bahwa budaya organisasi berkaitan dengan aspek subjektif dari seseorang dalam memahami apa yang terjadi dalam organisasi. Selain itu, budaya organisasi dapat menjadi karakteristik tetang melakukan sesuatu dalam organisasi. Hal ini tentunya akan memberikan pengaruh terhadap nilai-nilai, normanorma, keyakinan serta pola perilaku yang berkaitan dengan kegiatan bisnis yang dapat terjadi tanpa disadari. Namun demikian, kebudayaan dapat menjadi pengaruh yang signifikan pada perilaku seseorang dalam organisasi (Moeheriono, 2014:337).

Budaya organisasi akan mencerminkan perilaku individu dan kelompok yang akan membantu menciptakan stabilitas organisasi untuk sistem sosial dan menemukan pola berperilaku dari hasil norma-norma dan nilai-nilai yang terbentuk dalam sehari-hari. Hal ini sesuai dengan teori yang disampaikan oleh Pabundu Tika (2014:108) menyatakan bahwa organisasi yang kuat adalah menjadi pembangkit semangat yang paling berpengaruh dalam menentukan perilaku setiap karyawan sehingga mereka merasa lebih baik dengan apa yang mereka lakukan dan cenderung bekerja lebih keras. Hal ini dapat meberikan bahwa budaya organisasi dapat memberikan motivasi kepada anggota organisasi untuk hasil kinerja yang sesuai dengan yang diharapkan perusahaan. Dengan kata lain budaya organisasi berhubungan kuat dengan kinerja.

Keterkaitan pengaruh kuat budaya organisasi dengan kinerja di ungkapkan oleh Wibowo (2016: 248), dengan menyatakan sebagai berikut: Budaya organisasi dapat mempunyai dampak signifikan pada kinerja ekonomi jangka panjang, dalam hal ini budaya organisasi mungkin akan menjadi faktor yang lebih penting dalam mempertimbangkan keberhasilan dan kegagalan perusahaan dalam dekade yang akan datang, maka tidak jarang budaya organisasi yang dengan kuat menghalangi kinerja finansial jangka panjang, mereka berkembang dengan mudah, bahkan dalam perusahaan yang penuh dengan orang yang layak dan cerdas. Dengan demikian dampak yang baik akan dirasakan oleh perusahaan yang unggul.

Dalam sebuah budaya dapat menjadi identitas bagi organisasi. Budaya yang ada pada organisasi akan mencerminkan citra organisasi di mata orang lain. Apabila budaya tersebut bersifat positif maka akan bercitra positif pula,begitupun sebaliknya jika budaya organisasi bersifat negatif maka citra perusahaan dimata orang lainpun akan buruk. Adapun penelitian sebelumnya dari Resti Prasiska Chandra (2017) yang berjudul "Hubungan Budaya Organisasi dengan Kinerja Pegawai (Sudi kasus pada kantor Kecamatan Leuwisadeng Kabupaten Bogor". Dalam penelitian ini menggunakan indikator yaitu : Budaya organisasi (x) keagresifan, orientasi tim, kepribadian, performa tim, kesadaran diri dan kinerja (y) kualitas, Kuantitas, Tanggung jawab dan Pelaksanaan tugas. Hasil penelitian menyimpulkan bahwa Hasil penelitian mengungkapkan bahwa analisis koefisien korelasi product moment diketahui hasil $\mathrm{r}=0,520$ yang artinya antara variabel $\mathrm{X}$ budaya organisasi dengan variabel $\mathrm{Y}$ kinerja pegawai memiliki hubungan yang cukup kuat. Dengan koefisien determinasi sebesar $\mathrm{R}=0,2704$ yang berarti kontribusi variabel budaya organisasi dengan kinerja pegawai sebesar $27,04 \%$. Diketahui uji hipotesis koefisien korealsi $t_{\text {hitung }}>t_{\text {tabel }}$ dengan nilai $3,8502>1,6741$ artinya $\mathrm{Ha}$ 
diterima dan Ho ditolak artinya menunjukan bahwa terdapat hubungan positif antara budaya organisasi dengan kinerja pegawai.

\section{Konstelasi Penelitian}

Berdasarkan kerangka pemikiran yang telah dikemukakan diatas, maka disusun konstelasi penelitian sebagai berikut:

\begin{tabular}{|l|l|l|}
\multicolumn{1}{c|}{$\begin{array}{c}\text { Variabel }(\mathbf{X}) \\
\text { Budaya Organisasi: }\end{array}$} \\
1. Kesadaran Diri \\
2. Keagresifan \\
3. Kepribadian \\
4. Performa \\
5. Orientasi Tim \\
(Edison, Anwar, dan Komariyah \\
(2016:131)
\end{tabular}

\section{Gambar 1 Konstelasi Penelitian}

\section{Hipotesis Penelitian}

Dari uraian latar belakang dan kerangka pemikiran, maka dalam posisi ini penulis mengemukakan suatu hipotesis, bahwa:

1. Budaya organisasi pegawai Dinas Kesehatan Kota Bogor kurang baik.

2. Kinerja pegawai Dinas Kesehatan Kota Bogor cukup baik.

3. Diduga ada hubungan yang positif antara budaya organisasi dengan kinerja pegawai Dinas Kesehatan Kota Bogor.

\section{Jenis Penelitian}

Jenis penelitian yang digunakan dalam penelitian ini adalah penelitian deskriptif eksploratif, mengenai hubungan budaya organisasi dengan kinerja pegawai Dinas Kesehatan Kota Bogor. Penelitian ini disebut penelitian deskriptif ekspolratif karena teknik penelitian yang digunakan yaitu statistik observasi, statistik kualitatif/kuantitatif.

\section{B. METODE PENELITIAN}

\section{Jenis dan Sumber Data Peneitian Jenis Data Penelitian}

Data yang dikumpulkan penulis dalam penelitian ini dibedakan menjadi dua yaitu data kualitatif dan data kuantitatif:
1. Data kualitatif yang digunakan dalam penelitian ini adalah data yang berbentuk informasi seperti fenomena yang terjadi di perusahaan dan data jumlah pegawai yang diperoleh dari Sub Bagian Umum Kepegawaian Dinas Kesehatan Kota Bogor.

2. Data kuantitatif yang digunakan dalam penelitian ini berupa datadata/angka-angka mengenai data kehadiran pegawai pada Dinas Kesehatan Kota Bogor, dan data penilaian prestasi kerja pegawai Dinas Kesehatan Kota Bogor.

Data kuantitatif juga digunakan dalam penelitian ini untuk mengolah hasil survey dari kuesioner yang berhubungan dengan alat analisis statistik dimana akan diuji untuk menemukan ada atau tidaknya hubungan antara variabel budaya organisasi dengan kinerja karyawan.

\section{Sumber Data Penelitian}

Data yang akan dikumpulkan dalam penelitian ini berasal dari berbagai sumber, yaitu:

\section{Data Primer}

Penulis menggunakan data primer yang diperoleh dari hasil observasi, wawancara dengan pihak pegawai Dinas berupa data bagian-bagian bidang serta jumlah keseluruhan pegawai. Data primer juga dikumpulkan berbentuk hasil kuesioner yang dilakukan terhadap narasumber yang berasal dari pelaku yang terkait dengan persoalan untuk mengetahui hubungan budaya organisasi dan kinerja karyawan.

2. Data Sekunder

Diperoleh dari berbagai buku literature, artikel, tulisan-tulisan ilmiah serta situs/ website internet.

\section{Opersional Variabel}

Untuk memudahkan penelitian, maka penulis membuat konsep operasional variabel. Hal ini bertujuan untuk menterjemahkan variabel dengan tegas, sehingga menjadi faktor-faktor 
yang dapat diukur. Variabel yang digunakan dalam penelitian ini adalah budaya organisasi sebagai varibel indepeden dan kinerja sebagai variabel dependen. Untuk lebih jelas, operasional variabel akan dijelaskan atau diuraikan sebagai berikut:

\section{Tabel Operasional Variabel}

\begin{tabular}{|c|c|c|c|}
\hline Variabel & Indikator & Ukuran & Skala \\
\hline \multirow[t]{5}{*}{$\begin{array}{l}\text { Budaya } \\
\text { Organis } \\
\text { asi } \\
\text { (idepend } \\
\text { ent } \\
\text { variabel } \\
\text { ) }\end{array}$} & $\begin{array}{l}\text { Kesadaran } \\
\text { Diri }\end{array}$ & $\begin{array}{l}\text { 1. Anggota mendapatkan kepuasan atas pekerjaanya. } \\
\text { 2. Anggota selalu berusaha untuk mengembangkan diri dan } \\
\text { kemampuannya. } \\
\text { 3. Anggota menaati peraturan yang ada } \\
\text { 4. Anggota melakukan usaha-usaha untuk meberikan layanan } \\
\text { terbaik kepada pelanggan. }\end{array}$ & Ordinal \\
\hline & Keagresifan & $\begin{array}{l}\text { 1. Anggota penuh inisiatif dan tidak selalu bergantung pada } \\
\text { petunjuk pmpinan. } \\
\text { 2. Enggota menetapkan rencana dan berusaha untuk } \\
\text { menyelesaikan dengan baik. }\end{array}$ & Ordinal \\
\hline & Kepribadian & $\begin{array}{l}\text { 1. Setiap anggota saling menghormati dan memberikan salam } \\
\text { (greeting) pada saat perjumpaan. } \\
\text { 2. Anggota sangat menghargai dan siap melayani orang yang } \\
\text { datang } \\
\text { 3. Antar baian yang ada, memandang bagian lain sebagai } \\
\text { pelanggan internal yang harus dilayani. } \\
\text { 4. Anggota kelompok saling membantu. } \\
\text { 5. Masing-masing anggota saling menghargai perbedaan } \\
\text { pendapat. }\end{array}$ & Ordinal \\
\hline & Performa & $\begin{array}{l}\text { 1. Anggota selalu mengutamakan kualitas dalam } \\
\text { menyelesaikan pekerjaan. } \\
\text { 2. Anggota selalu berinovasi untuk menemukan hal - hal yang } \\
\text { baru dan berguna. } \\
\text { 3. Setiap anggota selalu berusaha untuk bekerja dengan efektif } \\
\text { dan efesien. }\end{array}$ & Ordinal \\
\hline & $\begin{array}{l}\text { Orientasi } \\
\text { Tim }\end{array}$ & $\begin{array}{l}\text { 1. Setiap tugas - tugas tim dilakukan dengan diskusi dan } \\
\text { disiergikan. } \\
\text { 2. Setiap ada permasalan dakam tim kerja selalu diselesaikan } \\
\text { dengan baik }\end{array}$ & Ordinal \\
\hline \multirow{4}{*}{$\begin{array}{l}\text { Kinerja } \\
\text { karyawa } \\
\mathrm{n} \\
\text { (depend } \\
\text { en } \\
\text { variable } \\
\text { ) }\end{array}$} & $\begin{array}{l}\text { Kualitas } \\
\text { kerja }\end{array}$ & $\begin{array}{l}\text { 1. Menyelesaikan pekerjaan sesuai dengan target. } \\
\text { 2. Menyelesaikan pekerjaan tepat pada waktunya. } \\
\text { 3. Beberapa banyak kesalahan yang diperbuat dalam bekerja }\end{array}$ & Ordinal \\
\hline & $\begin{array}{l}\text { Kuantitas } \\
\text { Kerja }\end{array}$ & $\begin{array}{l}\text { 1. Melaksanakan pekerjaan sesuai dengan prosedur yang di } \\
\text { tetapkan. } \\
\text { 2. Pemahaman pegawai dalam pekerjaan yang akan dikerjakan. } \\
\text { 3. Kemampuan pegawai dalam menyelesaikan tugas yang } \\
\text { diberikan. }\end{array}$ & Ordinal \\
\hline & $\begin{array}{l}\text { Pelaksanaan } \\
\text { Tugas }\end{array}$ & $\begin{array}{l}\text { 1. Kreatif dalam melaksanakan pekerjaan. } \\
\text { 2. Menyelesaikan pekerjaan tanpa melibatkan orang lain. } \\
\text { 3. Mampu menyelesaikan pekerjaan yang sulit. }\end{array}$ & Ordinal \\
\hline & $\begin{array}{l}\text { Tanggung } \\
\text { Jawab }\end{array}$ & $\begin{array}{l}\text { 1. Memiliki rasa tanggung jawab atas beban tugas yang } \\
\text { diberikan. } \\
\text { 2. Bersedia menerima konsekuensi atas keselahan dalam } \\
\text { pelaksanaan tugas. } \\
\text { 3. Kesediaan pegawai dalam target yang diberikan. }\end{array}$ & Ordinal \\
\hline
\end{tabular}


Metode Penarikan Sampel

Menurut Sugiyono (2016:80), populasi adalah wilayah generalisasi yang terdiri atas objek/subjek yang mempunyai kualitas dan karakteristik tertentu yang ditetapkan oleh peneliti untuk dipelajari dan kemudian ditarik kesimpulannya. Metode sampel dalam penelitian ini adalah menggunakan metode sensus. Populasi dalam penelitian ini adalah pegawai Dinas Kesehatan Kota Bogor dengan jumlah populasi 56 orang.

\section{Metode Pengumpulan Data}

Jenis sumber data yang digunakan penulis dalam penelitian ini adalah data primer dan data sekunder.

1. Data Primer

Data perimer merupakan data yang diperoleh secara langsung dari sumber pertama yang berkaitan dengan objek penelitian dan berhubungan dengan masalah yang diteliti, dimana teknik yang digunakan yaitu:

a. Observasi

Observasi sebagai teknik pengumpulan data mempunyai ciri yang spesipik bila dibandingkan dengan teknik yang lain, yaitu wawancara dan kuesioner. Jika wawancara dan kuesioner selalu berkomunikasi dengan orang, maka observasi tidak terbatas pada orang, tetapi juga objek-objek alam yang lain (Sugiyono, 2018:145).

b. Wawancara

Wawancara digunakan sebagai teknik pengumpulan data apabila ingin melakukan studi pendahuluan untuk menemukan permasalahan yang harus diteliti, dan juga apabila peneliti ingin mengetahui hal-hal dari responden yang lebih mendalam dan jumlah respondennya sedikit/kecil. (Sugiyono, 2018:137).

c. Kuesioner (Angket)

Kuesioner merupakan teknik pengumpulan data yang dilakukan dengan cara memberi seperangkat pertanyaan atau pernyataan tertulis kepada reponden untuk dijawabnya. Kuesioner merupakan teknik pengumpulan data yang efisien bila peneliti tahu dengan pasti variabel yang akan diukur dan tahu apa yang bisa diharapkan dari responden. Selain itu kuesioner juga cocok digunakan bila jumlah responden cukup besar dan tersebar di wilayah yang luas. Kuesioner dapat berupa pertayaan/pernyataan tertutup atau terbuka, dapat diberikan kepada responden secara langsung atau dikirim melalui pos, atau internet. (Sugiyono,2018:142).

2. Data Sekunder

Data sekunder merupakan data yang diperoleh secara tidak langsung atau melalui media perantara. Penulis mengumpulkan data-data dan bahan pustaka lainya dari teori yang relevan terhadap permasalhan yang diteliti seperti: buku, jurnal, dan penelitian terdahulu serta penyedia data pada Dinas Kesehatan Kota Bogor.

\section{Uji Kualitas Data}

Uji kualitas data merupakan sebuah penelitian yang mengukur variabel dengan menggunakan instrumen kuesioner harus dilakukan pengujian kualitas data yang diperoleh. Pengujian ini bertujuan untuk mengetahui apakah instrument yang digunakan valid atau reliabel sebab kebenaran data yang diolah sangat menentukan kualitas hasil penelitian.

1. Uji Validitas

Uji validitas merupakan derajat ketepatan antara data yang terjadi pada objek penelitian dengan daya yang dapat dilaporkan oleh peneliti. Dengan demikian data yang valid adalah data "yang tidak berbeda" antar data yang dilaporkan oleh peneliti dengan data yang sesungguhnya terjadi pada objek penelitian. Metode yang digunakan 
untuk menguji validitas dalam penelitian ini adalah metode korelasi product moment (Sugiyono, 2018:267).

Rumus:

$\mathrm{r}_{\mathrm{xy}}=\frac{\mathrm{n}(\mathrm{XY})-\left(\sum \mathrm{X}\right)(\Sigma \mathrm{y})}{\sqrt{\left[\left[\mathrm{n} \cdot \Sigma \mathrm{X}^{2}-\left(\sum \mathrm{X}\right)^{2}\right]\left[\mathrm{n} \cdot \varepsilon \Sigma \mathrm{y}-\left(\sum \mathrm{y}\right)^{2}\right]\right.}}$

Dimana:

$r_{\mathrm{xy}}=$ nilai koefisien pearson

$\mathrm{n} \quad=$ populasi

$\sum \mathrm{x}=$ jumlah nilai dalam distribusi budaya organisasi

$\sum \mathrm{Y}=$ jumlah nilai dalam distribusi kinerja

$\sum X Y=$ jumlah hasil kali antara budaya organisasi dan kinerja

Apabila $r_{\text {hitung }}>r_{\text {tabel }}$ maka data dapat dinyatakan valid, dan sebaliknya apabila $\mathrm{r}$ hitung $<\mathrm{r}$ tabel maka dinyatakan tidak valid.

Tabel Hasil Validitas Variabel Independen (Budaya organisasi)

\begin{tabular}{|c|c|c|c|c|c|}
\hline $\begin{array}{l}\text { Indikator } \\
\text { Budaya } \\
\text { Organisasi }\end{array}$ & $\begin{array}{l}\mathrm{N}_{0} \\
\text { Soal }\end{array}$ & $\mathrm{r}_{\text {hitung }}$ & $\begin{array}{c}r_{\text {tabel }} \\
n=30 \\
a=5 \%\end{array}$ & Keterangan & Kesimpulan \\
\hline \multirow{4}{*}{$\begin{array}{c}\text { Kesadaran } \\
\text { Diri }\end{array}$} & 1 & 0,5296 & 0,3610 & $\mathrm{I}_{\text {hitung }}>\mathrm{I}_{\text {tabel }}$ & Valid \\
\hline & 2 & 0,5383 & 0,3610 & $\mathrm{I}_{\text {hitumg }}>\mathrm{I}_{\text {taboll }}$ & Valid \\
\hline & 3 & 0,7075 & 0,3610 & $\mathrm{I}_{\text {hiting }}>\mathrm{I}_{\text {tibel }}$ & Valid \\
\hline & 4 & 0,6981 & 0,3610 & $\mathrm{I}_{\text {hithme }}>\mathrm{I}_{\text {tabel }}$ & Valid \\
\hline \multirow[t]{2}{*}{ Keagresifan } & 5 & 0,3991 & 0,3610 & $\mathrm{I}_{\text {hiting }}>\mathrm{I}_{\text {tabel }}$ & Valid \\
\hline & 6 & 0,5307 & 0,3610 & $\mathrm{I}_{\text {hithug }}>\mathrm{r}_{\text {tabel }}$ & Valid \\
\hline \multirow[t]{5}{*}{ Kepribadian } & 7 & 0,7031 & 0,3610 & $\mathrm{I}_{\text {hitumg }}>\mathrm{I}_{\text {tabol }}$ & Valid \\
\hline & 8 & 0,362 & 0,3610 & $\mathrm{I}_{\text {hitrumg }}>\mathrm{I}_{\text {tabol }}$ & Valid \\
\hline & 9 & 0,3251 & 0,3610 & $\mathrm{I}_{\text {hitumg }}>\mathrm{I}_{\text {tabel }}$ & Tidak Valid \\
\hline & 10 & 0,4658 & 0,3610 & $\mathrm{I}_{\text {hitumg }}>\mathrm{I}_{\text {tabel }}$ & Valid \\
\hline & 11 & 0,5428 & 0,3610 & $\mathrm{I}_{\text {hitrumg }}>\mathrm{I}_{\text {tabol }}$ & Valid \\
\hline \multirow[t]{3}{*}{ Performa } & 12 & 0,6478 & 0,3610 & $\mathrm{I}_{\text {hitumg }}>\mathrm{I}_{\text {tabel }}$ & Valid \\
\hline & 13 & 0,4376 & 0,3610 & $\mathrm{I}_{\text {hitumg }}>\mathrm{I}_{\text {tabel }}$ & Valid \\
\hline & 14 & 0,6746 & 0,3610 & $\mathrm{I}_{\text {hitume }}>\mathrm{I}_{\text {tabel }}$ & Valid \\
\hline \multirow{2}{*}{$\begin{array}{c}\text { Orientasi } \\
\text { Tim }\end{array}$} & 15 & 0,5379 & 0,3610 & $\mathrm{I}_{\text {hitume }}>\mathrm{I}_{\text {tabel }}$ & Valid \\
\hline & 16 & 0,4955 & 0,3610 & $\mathrm{I}_{\text {hitume }}>\mathrm{I}_{\text {tabel }}$ & Valid \\
\hline
\end{tabular}

Sumber Data : Output Excel (2018)

Berdasarkan tabel hasil validitas budaya organisasi, dengan $r_{\text {tabel }}$ 0,3610 dari 30 responden pernyataan yang valid 15 dan 1 pernyataan yang tidak valid.
Tabel Hasil Validitas Variabel dependen (Kinerja Karyawan)

\begin{tabular}{|c|c|c|c|c|c|}
\hline $\begin{array}{c}\text { Indikator } \\
\text { Kinerja } \\
\text { Karyawan }\end{array}$ & $\begin{array}{l}\text { No } \\
\text { Soal }\end{array}$ & $\mathbf{r}_{\text {hitung }}$ & $\begin{array}{c}\mathbf{r}_{\mathrm{tabel}} \\
\mathrm{n}=\mathbf{3 0} \\
\alpha=\mathbf{5} \%\end{array}$ & Keterangan & Kesimpulan \\
\hline \multirow{3}{*}{ Kualitas } & 1 & 0,5457 & 0,3610 & $\mathrm{r}_{\text {hitung }}>\mathrm{r}_{\text {tabel }}$ & Valid \\
\hline & 2 & 0,4329 & 0,3610 & $\mathrm{r}_{\text {hitung }}>\mathrm{r}_{\text {tabel }}$ & Valid \\
\hline & 3 & 0,436 & 0,3610 & $\mathrm{r}_{\text {hitung }}>\mathrm{r}_{\text {tabel }}$ & Valid \\
\hline \multirow{3}{*}{ Kuantitas } & 4 & 0,4409 & 0,3610 & $\mathrm{r}_{\text {hitung }}>\mathrm{r}_{\mathrm{tabel}}$ & Valid \\
\hline & 5 & 0,462 & 0,3610 & $\mathrm{r}_{\text {hitung }}>\mathrm{r}_{\text {tabel }}$ & Valid \\
\hline & 6 & 0,4471 & 0,3610 & $r_{\text {hitung }}>r_{\text {tabel }}$ & Valid \\
\hline \multirow{3}{*}{$\begin{array}{c}\text { Pelaksanaan } \\
\text { Tugas }\end{array}$} & 7 & 0,6493 & 0,3610 & $\mathrm{r}_{\text {hitung }}>\mathrm{r}_{\text {tabel }}$ & Valid \\
\hline & 8 & 0,5273 & 0,3610 & $r_{\text {hitung }}>r_{\text {tabel }}$ & Valid \\
\hline & 9 & 0,4865 & 0,3610 & $\mathrm{r}_{\text {hitung }}>\mathrm{r}_{\mathrm{tabel}}$ & Valid \\
\hline \multirow{3}{*}{$\begin{array}{c}\text { Tanggung } \\
\text { Jawab }\end{array}$} & 10 & 0,429 & 0,3610 & $\mathrm{r}_{\text {hitung }}>\mathrm{r}_{\text {tabel }}$ & Valid \\
\hline & 11 & 0,4242 & 0,3610 & $r_{\text {hitung }}>r_{\text {tabel }}$ & Valid \\
\hline & 12 & 0,36 & 0,3610 & $\mathrm{r}_{\text {hitung }}>\mathrm{r}_{\text {tabel }}$ & Tidak Valid \\
\hline
\end{tabular}

Sumber Data : Output Excel (2018)

Berdasarkan tabel hasil validitas budaya organisasi, dengan $r_{\text {tabel }}$ 0,3610 dari 30 responden pernyataan yang valid 11 dan 1 pernyataan yang tidak valid.

2. Uji Reliabilitas

Reabilitas menyangkut ketepatan alat ukur. Suatu alat ukur disebut memiliki reabilitasnya tinggi atau dapat dipercaya, jika alat ukur itu mantap, dalam artian bahwa alat ukur tersebut stabil, dapat diandalkan (dependability) dan dapat diramalkan (predictability). Suatu alat ukur yang mantap tidak berubah-ubah pengukurannya dan dapat diandalkan karena penggunaan alat ukur tersebut berkali-kali akan memberikan hasil yang serupa. Reabilitas juga memberi aspek ketepatan atau akurasi. Adapun menurut Sugiyono (2015: 365), untuk menguji reliabilitas dapat digunakan rumus Alpha Cronbach sebagai berikut:

Dimana:

$$
\mathrm{r}_{1}=\left[\frac{K}{k-1}\right]\left[1-\frac{\sum S i^{2}}{S t^{2}}\right]
$$

$\mathrm{r}_{\mathrm{i}}=$ nilai reliabilitas

$\mathrm{k}=$ mean kuadrat antar subyek

$\mathrm{S}_{\mathrm{t}}^{2}=$ varians total

$\sum \mathrm{S}_{\mathrm{i}}^{2}=$ mean kuadrat kesalahan 


\section{Tabel Kriteria penilaian terhadap koefisien $\alpha$ Crombach sebagai berikut:}

\begin{tabular}{|c|c|c|}
\hline No & Nilai $\alpha$ & Keterangan \\
\hline 1 & $\alpha<0,6$ & Kurang Reliabel \\
\hline 2 & $\alpha<0<0,8$ & Cukup Reliabel \\
\hline 3 & $\alpha<0,8$ & Sangat Reliabel \\
\hline
\end{tabular}

Berikut ini adalah hasil dari pengolahan data kuesioner setelah menggunakan software SPSS versi 23
a. Uji Reliabilitas Budaya Organisasi

Uji reliabilitas dapat dilihat pada kolom cronbach's alpha, bahwa data atau case yang valid berjumlah 15. Dapat diketahui bahwa nilai cronbach's alpha untuk variabel budaya organisasi sebesar 0,856 .

\section{Tabel Case Processing Summary}

\begin{tabular}{|c|c|c|c|}
\hline & & $\mathrm{N}$ & $\%$ \\
\hline \multirow[t]{3}{*}{ Cases } & Valid & 30 & 100.0 \\
\hline & Excluded & 0 & .0 \\
\hline & Total & 30 & 100.0 \\
\hline
\end{tabular}

Sumber data : output SPSS 23 (2018)

Tabel Reliability Statistics

\begin{tabular}{|r|r|r|}
\hline $\begin{array}{c}\text { Cronbach's } \\
\text { Alpha }\end{array}$ & $\begin{array}{c}\text { Cronbach's Alpha } \\
\text { Based on } \\
\text { Standardized Items }\end{array}$ & N of Items \\
\hline .856 & .856 & 16 \\
\hline
\end{tabular}

Sumber data : output SPSS 23 (2018)

Output case processing summary menjelaskan tentang jumlah data yang valid untuk diproses dan data dikeluarkan dapat dilihat bahwa data atau case yang valid berjumlah 15 dengan persentase $100 \%$ dan reliability statistic menunjukan bahwa crombach's alpha untuk variabel budaya organisasi sebesar 0,856 yang berarti diterima maka disimpulkan bahwa instrument peneitian telah reliabel.
Tabel Hasil Uji Reliabilitas Budaya Organisasi

\begin{tabular}{|c|c|c|c|c|}
\hline Variabel & $\begin{array}{c}\text { Item } \\
\text { Pertanyaan }\end{array}$ & $\begin{array}{c}\text { Crombach's } \\
\text { Alpha }\end{array}$ & $\begin{array}{c}\text { Crombach's } \\
\text { Alpha If } \\
\text { Item Deleted }\end{array}$ & Keterangan \\
\hline \multirow{4}{*}{ Budaya } & 1 & 0,856 & 0,727 & Reliabel \\
\cline { 2 - 5 } & 2 & 0,856 & 0,730 & Reliabel \\
\cline { 2 - 5 } & 3 & 0,856 & 0,723 & Reliabel \\
\cline { 2 - 5 } & 4 & 0,856 & 0,729 & Reliabel \\
\cline { 2 - 5 } & 5 & 0,856 & 0,733 & Reliabel \\
\cline { 2 - 5 } & 6 & 0,856 & 0,731 & Reliabel \\
\cline { 2 - 5 } & 7 & 0,856 & 0,728 & Reliabel \\
\cline { 2 - 5 } & 8 & 0,856 & 0,737 & Reliabel \\
\cline { 2 - 5 } & 9 & 0,856 & 0,729 & Reliabel \\
\cline { 2 - 5 } & 10 & 0,856 & 0,723 & Reliabel \\
\cline { 2 - 5 } & 11 & 0,856 & 0,731 & Reliabel \\
\cline { 2 - 5 } & 12 & 0,856 & 0,735 & Reliabel \\
\cline { 2 - 5 } & 13 & 0,856 & 0,723 & Reliabel \\
\cline { 2 - 5 } & 14 & 0,856 & 0,735 & Reliabel \\
\cline { 2 - 5 } & 15 & 0,856 & 0,732 & Reliabel \\
\hline
\end{tabular}

Sumber Data : Output Excel (2018)

b. Uji Reliabilitas Kinerja Karyawan

Uji reliabilitas dapat dilihat pada kolom crombach's alpha, bahwa data atau case yang valid berjumlah 12. Dapat diketahui bahwa nilai cronbach's alpha untuk variabel kinerja karyawan sebesar 0,781 .

Tabel Case Processing Summary

\begin{tabular}{|ll|r|r|}
\hline & \multicolumn{1}{|c|}{$\mathrm{N}$} & $\%$ \\
\hline Cases & Valid & 30 & 100.0 \\
& Excluded $^{\mathrm{a}}$ & 0 & .0 \\
& Total & 30 & 100.0 \\
\hline
\end{tabular}

Sumber Data : Output Excel (2018)

Output case processing summary menjelaskan tentang jumlah data yang valid untuk diproses dan data dikeluarkan dapat dilihat bahwa data atau case yang valid berjumlah 12 dengan persentase $100 \%$ dan reliability statistic menunjukan bahwa crombach's alpha untuk variabel budaya organisasi sebesar 0,781 yang berarti diterima maka disimpulkan bahwa instrument peneitian telah reliabel.

Tabel Hasil Uji Reliabilitas Kinerja

\begin{tabular}{|c|c|c|c|c|}
\multicolumn{5}{|c}{ Karyawan } \\
\hline \multirow{3}{*}{ Variabel } & $\begin{array}{c}\text { Item } \\
\text { Pertanyaan }\end{array}$ & $\begin{array}{c}\text { Crombach's } \\
\text { Alpha }\end{array}$ & $\begin{array}{c}\text { Crombach's } \\
\text { Alpha If Item } \\
\text { Deleted }\end{array}$ & Keterangan \\
\hline \multirow{4}{*}{ Kinerja } & 1 & 0,781 & 0,718 & Reliabel \\
\cline { 2 - 5 } & 2 & 0,781 & 0,722 & Reliabel \\
\cline { 2 - 5 } & 3 & 0,781 & 0,712 & Reliabel \\
\cline { 2 - 5 } & 4 & 0,781 & 0,10 & Reliabel \\
\cline { 2 - 5 } & 5 & 0,781 & 0,725 & Reliabel \\
\cline { 2 - 5 } & 6 & 0,781 & 0,716 & Reliabel \\
\cline { 2 - 5 } & 7 & 0,781 & 0,717 & Reliabel \\
\cline { 2 - 5 } & 8 & 0,781 & 0,706 & Reliabel \\
\cline { 2 - 5 } & 9 & 0,781 & 0,721 & Reliabel \\
\cline { 2 - 5 } & 10 & 0,781 & 0,726 & Reliabel \\
\cline { 2 - 5 } & 11 & 0,781 & 0,722 & Reliabel \\
\cline { 2 - 5 } & 12 & 0,781 & 0,723 & Reliabel \\
\hline
\end{tabular}




\section{Metode Pengolahan/ Analisis Data}

Setelah data diambil melalui proses metode pengumpulan data, langkah selanjutnya yaitu untuk melihat gambaran hasil penelitian dan menguji hipotesis dan selanjutnya dilakukan analisis data. Untuk mengetahui hubungan Budaya Organisasi dengan Kinerja Pegawai. Dengan variabel $\mathrm{X}$ (Budaya Organisasi) dan Y (Kinerja Pegawai).

1. Analisis Deskriptif / Kualitatif

Analisis deskriptif adalah statistik yang berkenaan dengan bagaimana cara mendeskripsikan, menggambarkan, menjabarkan, atau menguraikan data sehingga mudah dipahami.

Skala pengukuran, skala yang digunakan dalam penelitian ini adalah skala likert, adapun bobot nilai jawaban skala likert adalah sebagai berikut:

\section{Tabel Skala Likert}

\begin{tabular}{|l|c|}
\hline \multicolumn{1}{|c|}{ Jawaban Responden } & Skor \\
\hline Setuju/Selalu/sangat positif & 5 \\
\hline Setuju/Sering/positif & 4 \\
\hline Ragu-Ragu/Kadang-Kadang/netral & 3 \\
\hline Tidak Setuju/Hampir TidakPernah/negatif & 2 \\
\hline Sangat tidak setuju/tidak pernah/sangat negatif & 1 \\
\hline
\end{tabular}

Sumber: Sugiyono (2016: 168169)

Total dari nilai jawaban dari setiap pernyataan kemudian dibuatkan rentang skala untuk mengetahui tanggapan total responden. Dengan rumus sebagai berikut:

Tanggapan total responden $=\frac{\text { Skor Total Hasil Jawaban Responden }}{\text { Skor Tertinggi Responden }} \times 100$

\begin{tabular}{|c|c|c|c|c|c|}
\hline STS & TS & & & & \\
\hline $0 \%$ & & $40 \%$ & $60 \%$ & $80 \%$ & $100 \%$ \\
\hline Skala & \multicolumn{5}{|c|}{ Kriteria Penilaian } \\
\hline $0 \%-20 \%$ & \multicolumn{5}{|c|}{ Sangat tidak setuju/tidak pernah/sangat negative } \\
\hline $20 \%-40 \%$ & \multicolumn{5}{|c|}{ Tidak setuju/hampir tidakpernah/negative } \\
\hline $40 \%-60 \%$ & \multicolumn{5}{|c|}{ Ragu-Ragu/kadang-kadang/netral } \\
\hline $60 \%-80 \%$ & \multicolumn{5}{|c|}{ Setuju/sering/positif } \\
\hline $80 \%-100 \%$ & \multicolumn{5}{|c|}{ Setuju/selalu/sangatp } \\
\hline
\end{tabular}

2. Analisis Kuantitatif

Menganalisis data dengan menggunakkan angka-angka yang didapat dari penentuan skor untuk mempermudah perhitungan kedua variabel tersebut. Analisis data merupakan teknik yang digunakan untuk menganalisis data yang diperoleh dari hasil kegiatan penelitian tersebut yang termakna dan truji, maka diperlukan cara-cara tertentu dalam menganalisisnya.

a. Analisis Koefisien Korelasi (Rank Spearman)

Analisis koefisien korelasi digunakan untuk mengetahui seberapa besar tigkat keeratan atau hubungan antara variabel budaya organisasi sebagai variabel $\mathrm{X}$ dengan kinerja karyawan sebagai variabel Y, maka digunakan rumus Rank Spearman yang dinyatakan dalam rumus :

$$
\begin{aligned}
& \text { Rumus : } \mathbf{r}_{\mathrm{xy}}=1-\frac{6 \sum \boldsymbol{d i ^ { 2 }}}{\boldsymbol{n}\left(\boldsymbol{n}^{2-1}\right)}, \\
& \text { dimana } \sum d_{l}^{2}=\sum\left[R(X i)-R(Y i)^{2}\right. \\
& \text { (Sugiyono, 2016:191) } \\
& \mathrm{r}_{\mathrm{x}} \quad=\text { koefisien Rank Spearman } \\
& \mathrm{n} \quad=\text { ukuran sampel } \\
& \mathrm{R} \text { = rangking } \\
& \mathrm{d} i=\text { selisih dari pasangan } \\
& \text { ranking ke-1 }
\end{aligned}
$$

Dari hasil perhitungan koefisien korelasi (r), maka akan didapatkan hasil sebagai berikut:

1) Jika nilai $r=+1$,

Maka hubungan kedua variabel dinyatakan menuju kuat positif. Artinya jika budaya organisasi bertambah, nilai kinerja juga bertambah. Jika nilai budaya organisasi berkurang, maka berkurang juga nilai kinerja.

2) Jika nilai $r=-1$,

Maka hubungan kedua variabel dinyatakan menuju kuat negativ, artinya jika budaya organisasi bertambah, nilai variabel kinerja berkurang, jika nilai budaya organisasi berkurang, maka nilai kinerja berkurang.

3) Jika nilai $r=0$,

Maka hubungan kedua variabel dinyatakan menuju lemah (tidak ada hubungan). Artinya jika budaya organisasi bertambah atau berkurang, nilai kinerja tidak mengikutinya. Jika 
kinerja bertambah atau berkurang, nilai budaya organisasi tidak mengikutinya.

Menurut Sugiyono (2015: 231), untuk memberikan interpretasi terhadap kuatnya hubungan, dapat digunakan pedoman seperti yang tertera pada tabel berikut:

\begin{tabular}{|c|c|}
\multicolumn{1}{c|}{ Tabel Indeks Korelasi } \\
\hline Interval & Interpretasi \\
\hline $0,800-1,000$ & Sangat Kuat \\
$0,600-0,799$ & Kuat \\
$0,400-0,599$ & Sedang \\
$0,200-0,399$ & Rendah \\
$0,000-0,199$ & Sangat Rendah \\
\hline
\end{tabular}

Sumber : Sugiyono (2015: 231)

b. Analisis koefisien Determinasi Koefisien determinasi dimaksudkan untuk mengetahui besarnya kontribusi budaya organisasi sebagai variabel independen dengan kinerja pegawai sebagai variabel dependen pada Dinas Kesehatan Kota Bogor. Menurut Sugiyono (2011: 231) Koefisien determinasi dapat dihitung dengan rumus: $\quad \mathrm{KD}=\mathrm{r}^{2} \times$ $100 \%$

Keterangan:

$\mathrm{KD}=$ Nilai koefisien determinasi

$\mathrm{R}=$ Nilai koefisien korelasi

c. Uji Hipotesis Koefisien Korelasi

Uji hipotesis ini digunakan untuk membuktikan apa yang menjadi anggapan penulis yaitu adanya hubungan antara kedua variabel yang diteliti, maka diperlukan adanya pengujian hipotesis. Langkah-langkah pengujian hipotesis dengan menggunakan uji satu arah adalah sebagai berikut:

a. Menentukan Ho dan Ha

Ho : $r<0$, yaitu tidak ada hubungan nyata dan positif antara budaya organisasi dengan kinerja pegawai.

Ha : $r>0$, yaitu terdpat hubungan nyata dan positif antara budaya organisasi dengan kinerja pegawai.

b. Menentukan uji $\mathrm{t}$ (test) yang berguna untuk menguji tingkat signifikan dengan rumus:

$$
t=r \sqrt{\frac{(n-2}{1-r^{2}}}
$$

Keterangan:

$\mathrm{t}=\mathrm{t}$ hitung

$\mathrm{r}=$ koefisien korelasi

$\mathrm{n}$ = banyaknya responden

(Sugiyono, 2014,230)

Mencari (Tabel t) menggunakan $\alpha$ $=0,05$ dan derajat kebebasan $(\mathrm{dk}=\mathrm{n}-$ 2). Dengan menggunakan uji satu arah maka kriteria hasil pengujiannya adalah:

1) Terima Ho jika nilai thitung $\leq t_{\text {tabel }}$

Artinya tidak ada hubungan yang nyata antara budaya organisasi dengan Kinerja Karyawan.

2) Tolak Ho dan terima Ha jika nilai $t_{\text {hitung }}>t_{\text {tabel }}$

Artinya ada hubungan yang nyata antara budaya organisasi dengan Kinerja Karyawan.

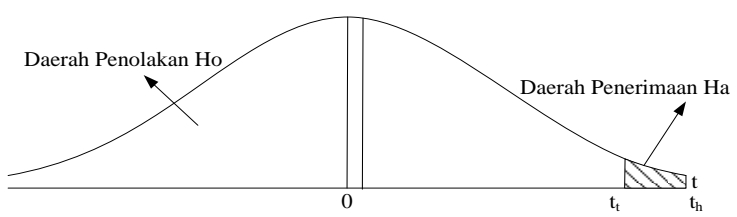

\section{Gambar Kurva Hasil Pengujian Hipotesis Korelasi}

\section{HASIL PENELITIAN}

\section{Hubungan Budaya Organisasi dengan Kinerja Pegawai Dinas Kesehatan Kota Bogor}

1. Analisis Koefisien Korelasi

Penulis menggunakan kuisioner dengan pengujian hasil pengolahan data Hubungan Budaya Organisasi dengan Kinerja Pegawai dengan menggunakan uji koefisien korelasi dengan responden sebanyak 56.

Berdasarkan hasil pengolahan dengan menggunakan SPSS mengenai Hubungan Budaya Organisasi dengan Kinerja Pegawai Dinas Kesehatan Kota Bogor. 


\section{Tabel Korelasi Budaya Organisasi dengan Kinerja Karyawan Rank Spearman (SPSS23)}

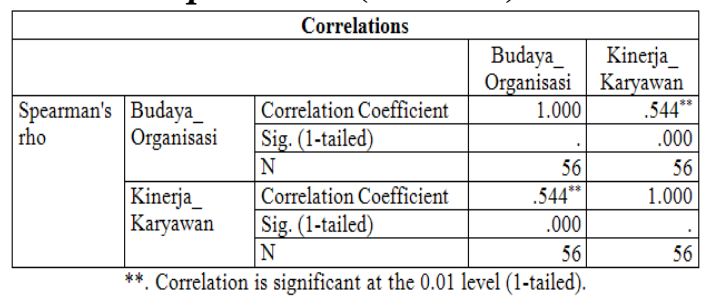

Sumber : output SPSS 23

Berdasarkan hasil perhitungan SPSS diatas dapat diketahui besarnya rank spearman adalah $\mathrm{r}=0,544$. Artinya, budaya organisasi dengan kinerja karyawan mempunyai hubungan yang sedang.

\section{Tabel Indeks Korelasi}

\begin{tabular}{|c|c|c|}
\hline Interval & Persentase & Interpretasi \\
\hline $0,800-1,000$ & & Sangat Kuat \\
\hline $0,600-0,799$ & & Kuat \\
\hline $0,400-0,599$ & 0,544 & Sedang \\
\hline $0,200-0,399$ & & Rendah \\
\hline $0,000-0,199$ & & Sangat Rendah \\
\hline
\end{tabular}

Sumber : Sugiyono (2015: 231)

2. Analisis Koefisien Determinasi

Dari perhitungan korelasi rank spearman adalah diketahui nilai korelasi sebesar $r=0,544$. Selanjutnya untuk mengetahui besarnya nilai koefisien determinasi dilakukan perhitungan sebagai berikut.

$$
\begin{aligned}
\mathrm{KD} & =\mathrm{r}^{2} \times 100 \% \\
& =0,544^{2} \times 100 \% \\
& =29,6 \%
\end{aligned}
$$

Berdasarkan perhitungan di atas, maka dapat diketahui bahwa nilai koefisien determinasi adalah $\mathrm{R}$ sebesar $29,6 \%$, hal ini menunjukan bahwa budaya organisasi memberikan kontribusi besar $29,6 \%$ sedangkan dengan $70,4 \%$ dipengaruhi oleh faktorfaktor lain di kinerja karyawan.

\section{Analisis Koefisien Korelasi}

Untuk mengetahui apakah hipotesis yang dibuat dapat diterima atau ditolak dan apakah hubungan budaya organisasi dengan kinerja karyawan, maka dilakukan uji hipotesis koefisien korelasi.

$$
\text { a. Hipotesis Statistik }
$$

Ho: $\mathrm{r}<0$, yaitu tidak ada hubungan yang nyata dan positif antara budaya organisasi dengan kinerja karyawan.

Ha: $r>0$, yaitu terdapat hubungan nyata atau positif antara budaya organisasi dengan kinerja karyawan.

b. Menentukan $t_{\text {hitung }}$

Untuk mencari thitung menggunakan rumus sebagai berikut.

$$
\begin{aligned}
& t=r \sqrt{\frac{(n-2)}{1-r^{2}}} \\
& t_{\text {hitung }}=\frac{0,544 \sqrt{56-2}}{\sqrt{1-(0,544)^{2}}} \\
& =\frac{3,997}{0,839} \\
& t_{\text {hitung }}=4,764 \quad
\end{aligned}
$$

c. Menentukan $t_{\text {tabel }}$

Nilai $t_{\text {tabel }}$ diperoleh dari tabel $\mathrm{t}$ dengan menggunakan nilai $\alpha=0,05$ dan $\mathrm{df}=\mathrm{n}-2$ atau $56-2=54$, maka diperoleh $t_{\text {tabel }} 1,674$.

d. Kurva

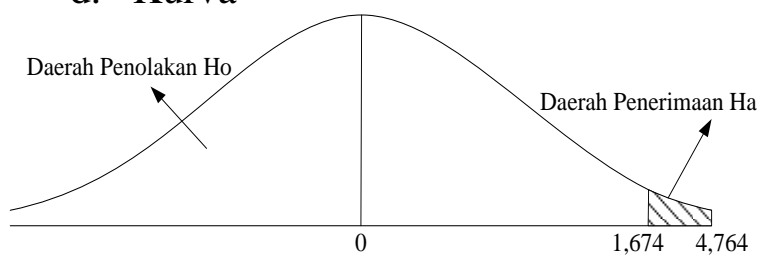

Gambar Kurva Uji Hipotesis

e. Hasil Uji Kurva

Nilai thitung $>t_{\text {tabel }}(4,764>1,674)$ maka Ha diterima Ho ditolak, jadi dapat dijabarkan bahwa terdapat hubungan yang cukup kuat antara budaya organisasi dengan kinerja karyawan pada Dinas Kesehatan Kota Bogor.

\section{KESIMPULAN}

\section{Kesimpulan}

Berdasarkan analisis tentang Hubungan Budaya Organisasi dengan Kinerja Pegawai Dinas Kesehatan Kota Bogor, maka pada bab penutup ini penulis menarik kesimpulan sebagai berikut.

1. Budaya organisasi pada Dinas Kesehatan Kota Bogor dengan responden sebanyak 56 orang, berdasarkan hasil nilai dan skor rata-rata empirik sebesar 64,51 
sementara skor rata-rata teoritik sebesar 45 dapat diartikan bahwa jawaban responden atas pernyataan pada instrument budaya organisasi atau variabel $X$ yaitu $(64,51<45)$ sehingga penulis mengambil kesimpulan bahwa budaya organisasi pada Dinas Kesehatan Kota Bogor relatif baik.

2. Kinerja pegawai pada Dinas Kesehatan Kota Bogor dengan responden 56 orang, berdasarkan hasil nilai skor rata-rata empirik sebesar 46,36 sementara skor rata-rata teoritik sebesar 33 dapat diartikan bahwa jawaban responden atas pernyataan pada instrument kinerja atau variabel Y yaitu (46,36 > 33 ) sehingga penulis mengambil kesimpulan bahwa kinerja pegawai pada Dinas Kesehatan Kota Bogor relatif baik. jika secara teori hasilnya adalah relatif baik.

3. Terdapat hubungan yang positif antara budaya organisasi dengan kinerja pegawai Dinas Kesehatan Kota Bogor. Dapat dilihat dari hasil analisis sebagai berikut:

a. Berdasarkan hasil analisis koefisien korelasi rank spearman diperoleh hasil $\mathrm{r}=0,544$, artinya hubungan budaya organisasi dengan kinerja pegawai Dinas Kesehatan Kota Bogor mempunyai hubungan dengan tingkat korelasi yang sedang.

b. Hasil perhitungan koefisien determinasi sebesar 29,6 hal ini menunjukan peranan atau kontribusi variabel (X) budaya organisasi terhadap variabel (Y) kinerja pegawai sebesar
$30 \%$ sedangkan sisanya

$70 \%$ dijelaskan oleh faktor-faktor lain diluar budaya organisasi yang tidak diteliti pada penelitian ini.

c. Hasil uji hipotesis diperoleh $t_{\text {hitung }}>t_{\text {tabel }}$ yaitu dengan nilai 4,764 $>1,674$. Yang berarti $\mathrm{Ha}$ diterima Ho ditolak. Jadi dapat disimpulkan terdapat hubungan yang positif antara budaya organisasi dengan kinerja pegawai pada Dinas

\section{DAFTAR PUSTAKA} Kesehatan Kota Bogor.

Ahidin Udin, Mutakin .A. 445-747-1-
SM.pdf. Jurnal Ilmiah Prodi
Manajemen r Universitas
Pamulang, Hubungan Budaya
Organisasi Dan Kinerja
Karyawan Pada PT. Syaka Putra
Transindo. Jakarta, Vol.1. No. 2 .
April 2014,

Amstrong. (2009), Manajemen Pengembangan Sumber Daya Manusia. Jakarta. Penerbit PUSTAKA PELAJAR.

Bohlander, G., \& Shell, S. (2010), Principle og Human Resource Management, $15^{\text {th }}$ ed, Mason, $\mathrm{OH}$ : South Western-Cengage Learning

Dessler, G. (2011). Manajemen Pengembangan Sumber Daya Manusia. Jakarta, Penerbit PUSTAKA PELAJAR.

Edison, E., Komariyah, I., dan Anwar, Y. (2016), Manajemen Sumber Daya Manusia Strategi Dan Perubahan Dalam Rangka Meningkatkan Kinerja Pegawai dan Organisasi. Bandung,Penerbit Alfabeta.

Erlinda, Widodo. (2012), Penilaian 
Kinerja.

Fahmi, I. (2016), Pengantar Manajemen Sumber Daya Manusia Konsep dan Kinerja. Jakarta, Penerbit Mitra Wacana Media.

(2013), Pengantar Manajemen Sumber Daya Manusia Konsep dan Kinerja. Jakarta, Penerbit Mitra Wacana Media.

Greenberg, J,. and Baron. R,. A,. (2016) Behavior on Organizations. New Jersey: Prentice-Hall.

Hasibuan, M. (2008), Manajemen Sumber Daya Manusia, Jakarta, Penerbit PT. Bumi Aksara.

Hartatik, I.,F., dan Henry. S. (2014), Buku Praktik Mengembangkan Sumber Daya Manusia.Jogjakarta, Penerbit Laksana.

Ilham., F., W. (2017). Hubungan Budaya Organisasi dengan Kinerja Karyawan Manufacture PT Tirta Investama Babakanpari Kabupaten Sukabumi. Universitas Pakuan.

Laras., R., Z. (2018). Hubungan Budaya Organisasi dengan Kinerja Karyawan pada Gumati Waterpark. Universitas Pakuan.

Mathis, and Jackson. (2012). Manajemen Pengembangan Sumber Daya Manusia. Jakarta. Penerbit PUSTAKA PELAJAR.

Kasmir. (2018) Manajemen Sumber Daya Manusia. Cetakan 4. Penerbit Rajawali Pers.

Kilman. (2016), Teori Perilaku dan Budaya Organisasi, Bandung, Penerbit PUSTAKA SETIA, Cetakan Pertama.

Kreitner, Robert and Angelo Kinciki. (2010) Organizational Behavior. New York: McGraw-Hill Companies, Inc.
Kusdyah, I. (2008). Manajemen Sumber Daya Manusia. Yogyakarta, CV.ANDI OFFSET.

Manulang, M. (2015), Dasar-Dasar Manajemen Yogyakarta, Penerbit UGM.

Mangkumanegara, A. P. (2015), Manajemen Sumber Daya Manusia Perusahaan, Bandung, Penerbit PT REMAJA ROSDAKARYA.

Mangkuprawira, S. (2011), Strategi Efektif Mengelola Karyawan. Bogor, Penerbit IPB Press.

McScane, S., L., Dan Glinow, V. (2014). Organizational Behavior Emerging Knowledge and Partice For The Real World, $5^{\text {th }}$ Ediiton, New York, McGrawhil.

Muhamad., D., A., R. (2018). Hubungan Budaya Organisasi dengan Kinerja Karyawan pada PT Paco Enginering Divisi Produksi. Universitas Pakuan.

Mondy. (2015), Manajemen Pengembangan Sumber Daya Manusia, Jakarta, Penerbit Pustaka Pelajar..

Moeheriono. (2012), Pengukuran Kinerja, Surabaya, Penerbit Raja Grafindo Persada.

Resti., P., C. (2017). Hubungan Budaya Organisasi dengan Kinerja Pegawai (Studi Kasus pada kantor Kecamatan Leuwisadeng). Universitas Pakuan.

Robbins., S., P. (2013). Perilaku Organisasi. Jakarta : Indeks Kelompok Gramedia. . (2014). Budaya Organisasi Dan Peningkatan Kinerja Perusahaan. Jakarta:Bumi Aksara, Cetakan kelima. (2015). Perilaku Organisasi Organizational Behavior. Jakarta : Penerbit Salemba Empat. 
Schein, Edgar H. (2016) Organizational Culture and Leaderahip. San Faransisko: Jossey-Bass.

Siagian, S., P. (2013) Manajemen Sumber Daya Manusia.Jakarta, Rineka Cipta.

Sinambela. L., P. (2012), Kinerja Pegawai : Teori Pengukuran dan Implikasi. Yogyakarta, Penerbit: Graha Ilmu.

Sugiyono. (2011), Metode Penelitian Kuantitatif, Kuallitatif, dan R\&D. Bandung, Penerbit ALFABETA.

(2015), Statistika Untuk Penelitian. Bandung, Penerbit Alfabeta.

, (2016), Metode Penelitian Kuantitatif, Kuallitatif, dan R\&D. Bandung, Penerbit ALFABETA.

, (2018), Metode Penelitian Kuantitatif, Kuallitatif, dan R\&D. Bandung, Penerbit ALFABETA.

Sutrisno, E. (2012). Manjemen Sumber Daya Manusia. Jakarta, Penerbit Kencana Prenada Media Group.

Swanepol., B. (2008), Human Resources Management, South African, The Berne Convention.

Tan., V. (2016), Teori Perilaku dan Budaya Organisasi, Bandung, Penerbit PUSTAKA SETIA, Cetakan Pertama.

Tika, M., P. (2014). Budaya Organisasi Dan Peningkatan Kinerja Perusahaan. Jakarta:Bumi Aksara, Cetakan kelima.

Prawirosentono, Sinambela Poltak. (2012), Kinerja Pegawai, Tanjung Barat. Jakarta, Penerbit GRAHA ILMU.

Wardiah, M., L,. (2016), Teori Perilaku dan Budaya Organisasi,
Bandung, Penerbit PUSTAKA SETIA, Cetakan Pertama.

Wibowo. (2016), Budaya Organisasi Sebuah Kebutuhan untuk Meningkatkan Kinerja Jangka Panjang, Jakarta, Penerbit PT. RAJAGRAFINDO PERSADA, Edisi ke 2, Cetakan ke 4.

Widodo, E., S. (2015), Manajemen Pengembangan Sumber Daya Manusia, Jakarta, Penerbit Pustaka Pelajar.

Wirawan. (2009), Evaluasi Kinerja Sumber Daya Manusia Teori Aplikasi dan Penelitian.Jakarta, Salemba Empat. 